sities like Gumma still only have 9.6-kilobit links to the NACSIS scientific inter-university network. In addition, the regional universities lack local area networks on campus, and the national universities are acquiring them only slowly, at a rate of one or two a year.

Asano of NACSIS admits that the issue of regional networks is "very political". But he argues that it is premature to establish such networks because there is a lack of "human resources" to manage them. A central management system is needed, he says, a job that the centre is starting to take on. In the meantime, NACSIS is concentrating on a plan to establish a six-megabit, super-high-capacity link between Tokyo and Kyoto.

But Kamae and his colleagues see no need for it. "We can easily supply that route with existing networks", Kamae says. "What is needed now is a bottoms-up approach".

It is not clear how such disagreements will be resolved. But even if NACSIS goes ahead with its plans, as seems likely, Kamae and his colleagues have already shown a remarkable capacity to establish links outside the NACSIS system.

David Swinbanks

\section{Who pulled the plug?}

UNIVERSITY scientists outside Japan who try in December to communicate via computer with their Japanese counterparts should not be surprised if the line suddenly goes dead for a few days. The silence is a result of government auditors trying to save the taxpayer a few yen.

Every year the National Centre for Science Information Systems (NACSIS) pulls the plug on the nation's university computer network to allow telecommunications carriers to bid on a contract to operate the system. Japan has several domestic telecommunication companies whose rates vary. And government financial auditors insist that the carriers must bid every year to provide the cheapest telecommunication links for NACSIS's nationwide computer network. To allow fair bidding, no carrier can provide telecommunication links for the computer network during the bidding process, which takes several days.

Last December, Japan was cut off from the outside scientific world for as much as a week. Shoichiro Asano of NACSIS says he is trying to shorten the bidding process. The centre also plans to install a back-up system using ordinary telephone lines so that the network remains open even during the bidding. D.S.

\title{
NSF pays price for success
}

\section{Washington}

WIDESPREAD acclaim, heady funding increases and thousands of satisfied scientists would be a dream come true for most science projects. But for the five-year-old computer network initiative of the $\mathrm{Na}$ tional Science Foundation (NSF), success has also meant a lot of headaches.

The initiative, called NSFNet, has grown steadily since it was created in 1987 as a nationwide 'backbone' research network. Earlier this year, the Administration requested more than $\$ 45$ million in 1993 for the agency's networking efforts, an increase of 38 per cent. In December, President George Bush signed legislation creating a National Research and Education Network (NREN) based on the NSFNet backbone. With annual funding expected to reach $\$ 1,000$ million by 1996 , NREN intends to connect not only research institutions but also schools and industry to a electronic web operating at 1,000 million bits per second.

It did not escape the notice of big business that all that money and responsibility was going to a little science agency. Longdistance telephone companies such as US Sprint also want to get into nationwide computer networking, and they complained bitterly that NSF had essentially handed over a potentially lucrative market to a handful of companies. The main contract had gone to Merit, Inc. (a non-profit consortium of Michigan universities) and Merit's subcontractors MCI and IBM, which handle the fibre optic lines and the routing hardware respectively. The three contractors then formed a fourth entity, Advanced Network and Services, Inc. (ANS), to handle network operations.

In its original plan, NSF had planned to 'recompete' its five-year contract with Merit in November. Normally, that would mean a simple request for applications and a selection of the winner. But pressure on the agency from the telecommunications industry has forced it to abandon its usual methods. Last year, it decided to extend the current contract by 18 months so that it could come up with a plan that would be fair to all concerned.

In the next week or two, NSF plans to issue a proposed solicitation for public comment. After weighing the comments, it will issue a final solicitation, and make awards in April 1993. Rather than retaining a single main contractor, NSF will make at least two awards for the lines and a third award for the routing equipment.

The process is a far cry from the type of small grants that NSF usually awards. "It keeps me up at night", admits Steven Wolff, director of the agency's network division.

Although congressional staff credit Wolff with making the best of a situation that simply got out of control, others say that NSF will not for long be able to balance the research community with the telecommunications industry. Some predict that NSF will be forced to privatize the network within a few years. "This thing has been growing even faster than NSF expected - they just ran up against telecommunications policy," says Frederick Weingarten, executive director of the Computing Research Association, a coalition of research universities.

Weingarten traces the problem to the mandate in the NREN legislation to serve society, not just the research community. "Once the [Administration] got the word education' into the title, it became tied up with a much bigger vision of building a national [network] infrastructure," he says.

When the telecommunications companies saw the scope of the legislation and the role that NSF would play in the network's development, they asked why a science agency - not to mention the US government - was in essence building the next telephone system. At a hearing in March before the House Science, Space and Technology subcommittee on science, industry officials complained that the NSF contract to Merit, IBM, MCI and ANS would allow those companies to essentially monopolize what promised to be a nationwide telecommunications network far beyond the research community.

"The entire group, which is now publicly self-characterized as a 'partnership', has total control over the $\$ 50$ million NSFNet backbone contract ... and [is] well positioned to win any NREN contracts in the future," complained William Schrader, president of Performance Systems International, a network services company.

Wolff acknowledges that the plunge into telecommunications policy has been a shock to NSF, but he is optimistic that the recompetition will allow the agency to continue to serve researchers and give companies a chance to compete. The government entered the field, he says, because scientists were not perceived to be a sufficiently lucrative market.

Once the recompetition is completed, NSF's next problem will be to know when to bow out. The network will someday connect commercial databases, schools and companies, and, if the lack of agreement among industry forces the agency to run the network for another five years or so, NSF may find it difficult to keep the focus on the research community.

On the other hand, giving it up too soon may leave researchers adrift. "NSF's not the right agency to run a nationwide network, says Weingarten. "But when it's finally taken out of their hands, I hope [the new owners] don't lose the ability to serve the research community as well."

Christopher Anderson 